introduced either in Britain or in Northern Ireland to penalize the unreasonable or even the dishonest patient.

We have recently seen, too, how in Eire a Government which was dissolved under a. cloud had practically all its representatives returned again at the election, because the people felt that they must have their "free" doctor.

I am thoroughly sick of the mawkish gentlemanliness and the unaltered committees with which we have met this social upheaval. At the moment the profession is standing around waiting for a change of Government or some other chance occurrence to help it. All we seem to have done in four years is to form a very unwieldy instrument, the Guild.

I submit, Sir, that we must "close our shop," act firmly against those black sheep who by their actions are making life so unpleasant for us at present, and then shake our fists aggressively at authority as the dockers or the miners do when they want something, and say to that authority: "You have gone far enough. You have degraded us and trifled with our honest hopes. There must be a change."

This letter may seem a bloodthirsty one, but it is nevertheless written by a very keen B.M.A. member who has sat hour after hour at Divisional meetings listening to proposals, directives from Headquarters, and incessant talk which, so far-let us face it-has achieved practically nothing.-I am, etc.,

$$
\text { Dungannon, N. Ireland. CONN MCCLUSKEY. }
$$

\section{Breaking Faith}

SIR,-I notice that in the Journal of June 23 three local authorities are the subject of an "Important Notice" in connexion with public health appointments; among them is the City of Manchester.

I am amazed that Manchester with its great Liberal tradition should fail to honour an Industrial Court award. A Joint Industrial Council award is implemented by the local authority treasurer as soon as declared without reference to the local authority other than formal report. A salary is a wage paid monthly, and there cannot be any conceivable reason why the wage earner should enjoy any right or advantage over the salary earner.

Collective bargaining is of the essence of democratic government, and here we have the spectacle of local authorities breaking faith with the very principles they are elected to defend. Is force, then, to be the final arbiter ? Shame on you, Manchester.-I am, etc.,

Keighley, Yorks.

H. M. Holt.

\section{POINTS FROM LETTERS}

\section{Entry into Practice}

Dr. W. Reginald Wilson (Doncaster) writes: Your leading article (Journal, June 16, p. 1372) speaks of the concern of the Government over the difficalty junior members of the profession are having in getting into general practice. Is it to be wondered at that men established in their work are reluctant under present conditions to admit newcomers to their surgeries, and to share their incomes?... If the Government would give up its fantastic ideas about trading in human flesh and blood, and allow a newcomer to give the established practitioner some monetary guarantee against all this risk and sacrifice, the machinery would quickly begin to work again. And, what is more, this would be to the inestimable advantage of the patients of the practice. For a normal man or woman who feels he has a proprietary interest in his clientele will be at constant personal pains to improve his own good name in their estimation. The opposite state of affairs all are now familiar with, and it constitutes one of the wettest of the wet blankets under which we struggle.

Correction.-We regret that in our report of the Annual Representative Meeting (Supplement, June 23, p. 253) Mr. J. L. Orr was erroneously reported as supporting the motion on the treatment of members of H.M. Forces as temporary residents under the N.H.S., moved by Dr. E. P. Johnson (p. 267). In fact it was supported by Dr. J. S. M. Ord (Glasgow).

\section{Association Notices}

Diary of Central Meetings

JULY

9 Mon. Committee on Psychiatry and the Law, 2 p.m.

9 Mon. Subcommittee re Future of Eye Service, Ophthalmic Group Committee, 4.30 p.m.

10 Tues. Registrars Subcommittee, Joint Committee for Consultants, 10.45 a.m. (B.M.A. House).

10 Tues. Joint Formulary Committee, 2 p.m.

11 Wed. Registrars Subcommittee, Joint Committee for Consultants, 10.30 a.m. (at Ministry of Health, Savile Row).

11 Wed. Planning Subcommittee, Occupational Health Committee, 11 a.m.

12 Thurs. Publishing Subcommittee, 10.30 a.m.

13 Fri. Ophthalmic Group Committee, 10 a.m. (Change of time.)

13 Fri. Ophthalmic Qualifications Committee, to follow Ophthalmic Group Committee.

18 Wed. Assistants and Young Practitioners Subcommittee, General Medical Services Committee, 2 p.m.

18 Wed. International Relations Committee, 2 p.m.

18 Wed. Conference of Tuberculosis and Diseases of the Chest Group (at Taylor Institution, Oxford). 5.30 p.m.

19 Thurs. Special Conference of Representatives of Local Medical Committees, 10 a.m.

19 Thurs. Staff Side, Whitley Committee C, 10.30 a.m. (at Room 105, Sub-ground floor, Ministry of Health, Whitehall, S.W.).

19 Thurs. Whitley Committee C (full committee), 12 noon (at 1, Richmond Terrace, Whitehall, S.W.).

26 Thurs. General Medical Services Committee, 11 a.m.

26 Thurs. Radiologists Group Committee, 2 p.m.

26 Thurs. Conference of Radiologists Group, 3 p.m.

27 Fri. Venereologists Group Committee, 11.30 a.m.

27 Fri. Conference of Venereologists Group, 2.30 p.m.

Aúgust

2 Thurs. Subcommittee on Maladjusted Children, Psychological Medicine Group Committee, 2 p.m.

\section{Branch and Division Meetings to be Held}

Cambridge and Huntingdon Branch.-At University Arms Hotel, Cambridge, Tuesday, July 10, 12.30 p.m., annual general meeting; 1.15 p.m., lunch ; 2.45 p.m., address by the President.

Metropolitan Counties Branch.-At B.M.A. House, Tavistock Square, London, W.C., Tuesday, July $10,2.30$ p.m., annual general meeting. President's Address by Mr. A. Lawrence Abel : "Pitfalls of Planning."

Norfolk Branch.-At The Assembly House, Theatre Street, Norwich, Thursday, July $12,3.15$ p.m., annual meeting. A Brains Trust will follow.

South Wales and Monmouthshire Branch.-At B.M.A. Welsh House, 195, Newport Road, Cardiff, Thursday, July 12 3.15 p.m. Presidential Address by Dr. J. D. Williamson: "Lord Lister and his Influence on Modern Life."

\section{Meetings of Branches and Divisions MERSEYSIDE BRANCH}

The annual meeting of the Merseyside Branch was held on June 8 at Liverpool, and was attended by 65 members and friends. Dr. P. Y. Lyle, of Southport, was elected president for the ensuing year; Dr. R. W. L. Pearson, of Birkenhead, the president-elect for 1952; and Dr. V. Cotton Cornwall was reelected secretary and treasurer.

The meeting was followed by a dinner at which the principal guests were Professor Sir Henry Cohen, President of the British Medical Association for 1950-1; Dr. Robert Coope, president of the Liverpool Medical Institution; Mr. T. Keeling, chairman of the Board of Governors and the Liverpool Regional Hospital Board; Dr. T. L. Dowell, president of the North Lancashire and Westmorland Branch of the B.M.A.; and Dr. W. Leak, president of the South Lancashire and East Cheshire Branch of the B.M.A.

Sir Henry, in the course of his speech, reviewed the work of the Association during the last year and pleaded that a larger number of people should interest themselves in the running of the Association. He emphasized that criticism was a good thing, but that it should be constructive and from the inside. 